\title{
A Study on Customer Relationship Management
}

\author{
T.R.Thiruvenkatraj \\ Assistant Professor, Bharath Niketan Engineering College, Theni, Tamilnadu.
}

\begin{abstract}
CRM is a strategy that focuses on building strong relationship with customer and potential customer for creating and maintaining a loyal customer base. Customer relationship management is a term that refers to practices, strategies and technologies that companies use to manage and analyze customer interactions and data throughout the customer lifecycle, with the goal of improving business relationships with customers, assisting in customer retention and driving sales growth. CRM are intended to gather information on customers across different channels or points of contact between the customer and the company which could include the company's website, telephone, live chat, direct mail, marketing materials and social media. CRM systems can also give customer-facing staff detailed information on customers' personal information, purchase history, buying preferences and concerns. Organization that adopt CRM can learn more about their customer and offer more personalized product and service as they receive relevant information daily in a way that allow them to spot trend. As a result it reduces the cost, increases efficiency and improve customer satisfaction.
\end{abstract}

Key words: CRM, Customer

\section{Introduction}

The art of managing the organization's relationship with the customers and prospective clients refer to customer relationship management. In simpler words, customer relationship management refers to the study of needs and expectations of the customers and providing them the right solution. CRM is all aspects of interactions that a company has with its customers, whether it is sales or service-related. While the phrase customer relationship management is most commonly used to describe a business-customer relationship (B2C), CRM is also used to manage business to business (B2B) relationships. Information tracked in a CRM system includes contacts, clients, contract wins and sales leads and more.

\section{Review Of Literature}

Mueller characterises customer relationship management aspect of the business as a highly dynamic, and convincingly argues that businesses have to adopt a proactive approach in devising relevant programs and initiatives in order to remain competitive in their industries. Sinkovics and Ghauri relate the necessity for engaging in customer relationship management to high cost of direct sales, highly intensifying level of competition in the global level, and need for information about various aspects of the business in general, and consumer behaviour in particular, that can be used to increase the levels of sales.

According to Peppers and Rogers, there is global tendency in customer relationship management that relates to the shift from transactional model towards the relationship model. In other words, Peppers and Rogers argue that satisfying customer needs as a result of on-time transaction is not sufficient today in order to ensure the long-term growth of the businesses.

Instead, businesses have to strive to maintain long-term relationships with their customers in order to maintain flexibility to adopt their increasing expectations and thus achieving their life-long loyalty. Peppers and Rogers further stress that, businesses that refuses to acknowledge this tendency in the global marketplace would be risking their market share and growth prospects in the future.

\section{Concept of CRM}

Customer Relationship Management is a complex process which is based on a good Knowledge of habits and needs of customers. It assumes constant collection of Information of customer's behavior. There are four primary reasons why Organization adjusts their business processes to customers' needs:

- Retention of existing customers,

- Attracting new customers,

- Encourage customers to deepen cooperation with organization

- Informing customers about portfolio of products, services and communication Channels, with aim of increasing profits or prevent losses. 


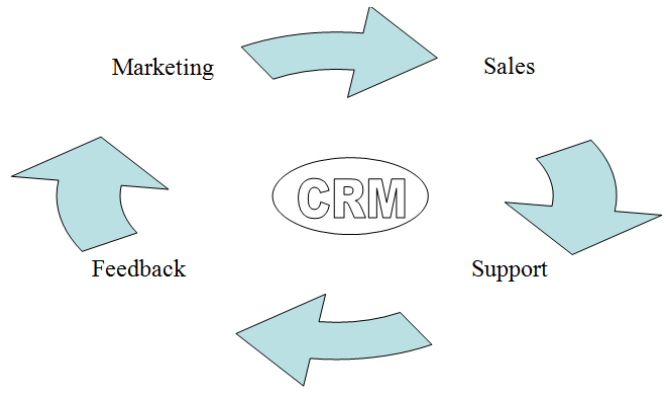

Need for Customer Relationship Management

* Customer Relationship Management leads to satisfied customers and eventually higher business every time.

* Customer Relationship Management goes a long way in retaining existing customers.

* Customer relationship management ensures customers return back home with a smile.

- Customer relationship management improves the relationship between the organization and customers Such activities strengthen the bond between the sales representatives and customers.

\section{Steps to Customer Relationship Management}

$\checkmark$ It is essential for the sales representatives to understand the needs, interest as well as budget of the customers.

Don't suggest anything which would burn a hole in their pockets.

$\checkmark \quad$ Never tell lies to the customers.

Convey them only what your product offers. Don't cook fake stories or ever try to fool them.

$\checkmark \quad$ It is a sin to make customers waiting.

Sales professionals should reach meetings on or before time. Make sure you are there at the venue before the customer reaches.

$\checkmark \quad$ A sales professional should think from the customer's perspective.

Don't only think about your own targets and incentives. Suggest only what is right for the customer. Don't sell an expensive mobile to a customer who earns rupees five thousand per month. He would never come back to you and your organization would lose one of its esteemed customers.

$\checkmark$ Don't oversell.

Being pushy does not work in sales. It a customer needs something; he would definitely purchase the same. Never irritate the customer or make his life hell. Don't call him more than twice in a single day.

$\checkmark \quad$ An individual needs time to develop trust in you and your product.

Give him time to think and decide.

$\checkmark \quad$ Never be rude to customers.

Handle the customers with patience and care. One should never ever get hyper with the customers.

$\checkmark \quad$ Attend sales meeting with a cool mind.

Greet the customers with a smile and try to solve their queries at the earliest.

$\checkmark \quad$ Keep in touch with the customers even after the deal.

Devise customer loyalty programs for them to return to your organization. Give them bonus points or gifts on every second purchase.

$\checkmark$ The sales manger must provide necessary training to the sales team to teach them how to interact with the customers.

Remember customers are the assets of every business and it is important to keep them happy and satisfied for successful functioning of organization.

\section{The Customer Relationship Management Strategy}

Customer relationship management is often thought of as a business strategy that enables businesses to improve in a number of areas. The CRM strategy allows you to following:

- Understand the customer

- Retain customers through better customer experience

- Attract new customers

- Win new clients and contracts

- Increase profitably

- Decrease customer management costs etc... 


\section{The Business Benefits of CRM}

The biggest benefit most businesses realize when moving to a CRM system comes directly from having all your business data stored and accessed from a single location. Before CRM systems, customer data was spread out over office productivity suite documents, email systems, mobile phone data and even paper note cards and Rolodex entries. Storing all the data from all departments in a central location gives management and employees immediate access to the most recent data when they need it. Departments can collaborate with ease, and CRM systems help organization to develop efficient automated processes to improve business processes.

Other benefits include a 360-degree view of all customer information, knowledge of what customers and the general market want, and integration with your existing applications to consolidate all business information.

\section{CRM Solutions Today}

CRM solutions give organizations business data to help provide services or products that your customers want, offer better customer service, help sales teams to cross-sell and up-sell more effectively, close deals, retain current customers and to better understand exactly who your customers are. Organizations frequently look for ways to personalize online experiences through tools such as help-desk software, email organizers and different types of enterprise applications.

\section{CRM Concept Success Factors}

CRM strategies, organizational structures and cultures, employees and top management, communication channels as well as information technology can positively and negatively affect acceptance and success of CRM concept. There is cause- effect relationship between mentioned factors, since establishment of proper CRM strategy, it's an acceptance in organization and by employees, selection of right CRM technology and its integration with channels of communication are the key factors of a successful CRM concept.

\section{Conclusion}

A Customer relationship management is useful for many reasons. It helps companies keep track of shopping trends, maintain positive relationships with their customer base and follow support issues. Also, sales personnel can drive deals or sales information by communication to customers to draw them back to their business. Understanding what type of customers a company has is also important because it can help them to have sales in the future. It is about concerned with attracting, maintaining and enhancing customer relationship in organizations. CRM goes beyond the transactional exchange and enables the marketer to estimate the customer's sentiments and buying intentions so that the customer can be provided with products and services before the starts demanding. Customers are the backbone of any kind of business activities, maintaining relationship with them yield better result.

\section{References}

[1]. Bull C., (2003). "Strategic issues in customer relationship management (CRM) implementation" Business Process Management Journal.

[2]. Bygstad, Bendik. (2003), "The Implementation Puzzle of CRM Systems in Knowledge Based Organizations". Information Resources Management Journal

[3]. Conway, D. K., Fitzpatrick J.M. (1999). The Customer Relationship Revolution - A methodology for creating golden customers.

[4]. GEFEN, D (2002). "Implementation Team Responsiveness and User Evaluation of Customer Relationship Management: A QuasiExperimental Design Study of Social Exchange Theory". Journal of management information systems (0742-1222), 19 (1), p. 47.

[5]. Marble, R. (2000), "Operationalising the implementation puzzle: an argument for eclecticism in research and practice". European Journal of Information Systems. 